\title{
Eco-compensation and Harmonious Regional Development in China
}

\author{
LIU Chunla ${ }^{1,2}$, LIU Weidong ${ }^{1}$, LU Dadao ${ }^{1}$, CHEN Mingxing ${ }^{1}$, Michael DUNFORD ${ }^{1,3}$, XU Mei $^{4}$ \\ (1. Institute of Geographic Sciences and Natural Resources Research, Key Laboratory of Regional Sustainable Development Modeling, \\ Chinese Academy of Sciences, Beijing 100101, China; 2. University of Chinese Academy of Sciences, Beijing 100049, China; 3. School \\ of Global Studies, University of Sussex, Brighton BN1 9QN, Sussex, UK; 4. College of Tourism, Central South University of Forestry \\ and Technology, Changsha 410004, China)
}

\begin{abstract}
Harmonious regional development poses difficult problems, especially in so far as the harmonious regional development of ecological resources is concerned. China has explored several eco-compensation models, and in each province eco-compensation has different characteristics. These methods have had significant impacts. The aim of this paper is first to examine the meaning of ecocompensation and to present a framework for analyzing it. Next the development of eco-compensation in China is examined. Finally, four typical models of eco-compensation are compared: the government financial transfer payment compensation model; the ecological resource exploiters' payment compensation model; the ecological destruction compensation model; and the ecological resource tax collection compensation model. Each model has its own unique feature and potential to contribute to harmonious regional development.
\end{abstract}

Keywords: eco-compensation; harmonious regional development; China

Citation: Liu Chunla, Liu Weidong, Lu Dadao, Chen Mingxing, Dunford Michael, Xu Mei, 2016. Eco-compensation and harmonious regional development in China. Chinese Geographical Science, 26(3): 283-294. doi: 10.1007/s11769-015-0758-x

\section{Introduction}

In China, harmonious regional development has been problematic for researchers, government officials, and the public (Lu and Liu, 2002; Lu and Fan, 2012), as it is not confined to harmonious development between regions, but also refers to harmonious relationships between economic development and the sustainable exploitation of ecological resources (Scott et al., 1998; Mäler, 2000; Yang, 2004; Straton, 2006; Fan, 2007; Sun, 2007). Especially in the 21 st century, we face the challenge of dramatically transforming the way we view and interact with our eco-resource systems. Healthy ecoresource systems have their own potential market values (Millennium ecosystem assessment, 2005), and healthy eco-resource system services are essential for the main- tenance of harmonious regional development.

Eco-compensation is a response to growing environmental pressures and the possibilities of using markets, and market-like instruments to grapple with them. The implementation of such ecological environmental policies and methods can help coordinate regional development relationships (Mao et al., 2002; Wu et al., 2003; Mao and Zeng, 2006; Qin and Kang, 2007; Yang et al., 2007; Dai et al., 2012; Xu et al., 2012). In recent years greater accessibility and greater regional interdependence have led to greater interest in inter-regional ecocompensation (Liu, 2007). In an interdependent world a lack of eco-compensation can result in imbalanced regional development (Zhang, 2007), and appropriate eco-compensation measures can facilitate the coordination of regional relationships (Wang, 2009). Many re-

Received date: 2014-05-10; accepted date: 2014-10-25

Foundation item: Under the auspices of National Natural Science Foundation of China (No. 41125005, 41430636), Open Fund Project of Hunan Provincial Key Research Base of Social Sciences for Human Settlements (No. RJ14K04), Natural Science Foundation of Hunan Province (No. 2015JJ3179)

Corresponding author: CHEN Mingxing. E-mail: chenmx@igsnrr.ac.cn

(C) Science Press, Northeast Institute of Geography and Agroecology, CAS and Springer-Verlag Berlin Heidelberg 2016 
searchers in China have discussed the influence of eco-compensation on harmonious regional development considering this relationship from a variety of angles (Wu et al., 2003; Zhang, 2007; Wang, 2009; Hou et al., 2011). These studies show that eco-compensation greatly affects regional development, while this research into the relationship between eco-compensation and regional development is reflected in the overall design, implementation, and evaluation of eco-compensation projects (Hou et al., 2012).

The relationship between eco-compensation and regional development has already attracted widespread attention of the scholars and practitioners. Major study fields and subjects are as follows:

(1) eco-compensation and regional ecological resources and environment. Researches have shown that the implementation of eco-compensation projects is a primary factor influencing ecologically sustainable regional development. Generally, in the period of the implementation of eco-compensation projects, the local ecological environment quality was improved greatly. But once the eco-compensation project was discontinued, the situation confronting the local ecological environment was much more hazardous (Wunder and Albán, 2008). How to maintain the positive effects of completed eco-compensation projects on the local ecological environment is the key point for practical work and theoretical research in future.

(2) Eco-compensation and the farming household economy. The implementation of eco-compensation projects reduced the labor input in the crop growing and animal raising industries (Zhi et al., 2004), and enlarged the scope of farming household economies, as farmers can search for other ways to increase income, such as migration, doing second jobs, developing ecological tourism, etc. (Pagiola, 2008; Johnson and Maxwell, 2011). But owing to differences in peasant household income and undifferentiated eco-compensation policies, there are two opposite influences on the farming household economy. For low income farmers, their new income will increase greatly their overall income after they accept eco-compensation. For high income farmers, the new income will not be sufficient to prevent a considerable reduction in their overall income after they accept eco-compensation. In this second case the protection and preservation of the ecological environment leads to profits loss from the production of agricultural products and animal by-products (Muñoz-Piña et al., 2008).

(3) Eco-compensation and the regional economy. Generally, eco-compensation accelerated the readjustment of industrial structures in project regions, optimized and reallocated resources, and improved industrial restructuring efficiency and the share of intensively-farmed land (Bennett, 2008). In poor regions, owing to transfer payment from the national/provincial exchequer, eco-compensation greatly increased local finance (Muñoz-Piña et al., 2008), although eco-compensation also, of course, had negative effects on the regional economy (Pagiola et al., 2005; Locatelli et al., 2008).

(4) Eco-compensation and social development. On the one hand, eco-compensation alleviated poverty, and offered more social welfare to poor people. By providing a fund, technology, medical treatment, material objects, education, etc., eco-compensation increased poor people' economic and non-economic income (Pagiola et al., 2005; Tschakert, 2007; Bennett, 2008; Muñoz-Piña et al., 2008; Pagiola, 2008). On the other hand, eco-compensation also adversely affected social fairness and efficiency (Pascual et al., 2010; Sommerville et al., 2010). Eco-compensation increased the size of the idle rural labor force (Hou et al., 2011), and generated some problems.

In all, current research into eco-compensation and regional development is not so voluminous in quantity, is mainly qualitative and descriptive, and mainly comprises case studies. Studies summing up theoretically the relationships of eco-compensation models and harmonious regional development are few, but are of great significance. Studying the overall framework of eco-compensation, analyzing its relationship with regional development, exploring current practice and identifying four typical models of eco-compensation are therefore important tasks for researchers and policy makers and implementers.

The major objective of this paper is accordingly to analyze the nature of eco-compensation and typical models for harmonious regional development in China, then examines the meaning of eco-compensation and its relationship with harmonious regional development, and outlines the main developmental situations in which eco-compensation issues have arisen in China and outlines some typical examples, lastly identifies four typi- 
cal models of eco-compensation. The findings provide useful insights into the quest for harmonious regional development.

\section{A Conceptual Framework for Analysis of 'Eco-compensation'}

\subsection{Concept and meaning}

Different researchers have employed various terms for eco-compensation. Some of these terms are listed in Table 1.

All of these terms can be classed into two categories. One stresses marketization and the concept of payment, such as payments for environmental services (Wunder, 2005; Muradian and Rival, 2013), environmental services payments (Bienabe and Hearne, 2006; Kalacska et al., 2008), compensation for ecosystem services (Zheng and Zhang, 2006), environmental services payments (Bienabe and Hearne, 2006; Kalacska et al., 2008).

The other is more general, not only containing the marketization concept of payment, but also the moral and social equity notion of compensation of eco-benefit losers, such as eco-compensation (Mao et al., 2002; Yang et al., 2013), ecological compensation (Cuperus et al., 1999; Brown et al., 2013), ecology compensation (Wang and Ma, 2002; Mao et al., 2008), and environmental compensation (Cowell, 1997; Rundcrantz and Skärbäck, 2003). This concept derives from welfare economics. The idea is that the use of ecosystem services is not paid for and so is associated with a range of externalities. To internalize these externalities losers can pay the gainers not to undertake actions with undesirable side effects, or gainers can compensate the losers so that an activity can go ahead without making the losers worse-off.

Table 1 Eco-compensation terms

\begin{tabular}{|c|c|}
\hline Term & Researchers \\
\hline Eco-compensation & Mao et al., 2002; Yang et al., 2013 \\
\hline Ecological compensation & Cuperus et al., 1999; Brown et al., 2013 \\
\hline Ecology compensation & Wang and Ma, 2002; Mao and Wang, 2008 \\
\hline $\begin{array}{l}\text { Payments for } \\
\text { environmental services }\end{array}$ & Wunder, 2005; Muradian and Rival, 2013 \\
\hline $\begin{array}{l}\text { Environmental } \\
\text { compensation }\end{array}$ & $\begin{array}{l}\text { Cowell, 1997; Rundcrantz and } \\
\text { Skärbäck , } 2003\end{array}$ \\
\hline $\begin{array}{l}\text { Compensation for } \\
\text { ecosystem services }\end{array}$ & Zheng and Zhang, 2006 \\
\hline $\begin{array}{l}\text { Environmental services } \\
\text { payments }\end{array}$ & $\begin{array}{l}\text { Bienabe and Hearne, 2006; } \\
\text { Kalacska et al., } 2008\end{array}$ \\
\hline
\end{tabular}

As to the problem of what eco-compensation intrinsically is, academics have also not given uniform answers (Cuperus et al., 1996; Babcock et al., 1997; Cuperus et al., 2001; Sara et al., 2002; Jenkins et al., 2004; Pagiola and Platais, 2007; Engel et al., 2008). To sum up, there are following viewpoints.

(1) Resources economy theory. Eco-compensation mainly eliminates the negative effects of externalities on resource allocation, and aims to realize ecological resources' economic value (Coase, 1960; Wunder, 2005; Engel et al., 2008; Ma et al., 2012).

(2) Benefit game theory. Eco-compensation mainly seeks to coordinate and solve the conflict between the protection of the eco-environmental rights, subsistence rights and development rights of different interest groups (Cowell, 1997; Merlo and Rojas Briales, 2000; Murray and Abt, 2001; Mao et al., 2002; Wunder, 2005).

(3) Environmental protection theory. Eco-compensation aims to solve ecological environmental problems, and to promote ecological environmental protection (China Ecological Compensation Mechanism and Policy Research Team, 2007; Li et al., 2009; Hou et al., 2012).

(4) Social justice theory. Via eco-compensation, the inequality between environmental resources property rights and development rights can be redressed (Wu et al., 2003; Li et al., 2007).

(5) Regional development theory. Eco-compensation can promote the integrated development of urban and rural areas, and of different regions (Pagiola et al., 2005; Kosoy et al., 2007; Li et al., 2007; Sun and Zhou, 2008; Zhang et al., 2010).

(6) Policy theory. Eco-compensation is an institutional arrangement, which aims to promote a harmonious relationship between environmental protection and the regional ecological economy (Cowell, 2000; Pagiola et al., 2005; Li et al., 2006; Pagiola and Platais, 2007; Yang et al., 2007; Dai and Zhao, 2010; Pan et al., 2010). As can be seen from the survey of Chinese research, most scholars use the phrase 'eco-compensation'. As this paper also deals with the Chinese case, it will also use the phrase 'eco-compensation' which concisely describes the purpose and is easy to comprehend.

\subsection{Basic framework and features}

Eco-compensation encompasses rewards for protecting ecological systems and natural resources, payments for 
losses caused by damage to eco-systems and natural resources by environmental polluters and compensation for losers (China ecological compensation mechanism and policy research team, 2007). Assuming valuation problems can be resolved, eco-compensation is an effective way to transform the external, non-market environment value into real financial incentives, and aims in this way to encourage the participants to provide sustainably more ecosystem services (Engel et al., 2008). Eco-compensation differs from general environmental economic policies and command and control environmental policies. Traditional methods emphasize environmental internalization and negative externalization and help to prevent environmental damage behavior, but they do not encourage people actively to protect the environment. Eco-compensation addresses the internalization of environmental externalities, and environmentalists receive benefits; positive incentives are offered to protect the environment, and can result in increased public support and cooperation (Sven et al., 2008). Who complements whom, how much compensation should be provided, and how to provide compensation are the core problems of eco-compensation (Mao et al., 2002; Wu et al., 2003; Engel et al., 2008; Hou et al., 2011; Xu et al., 2012) (Fig. 1).

First, eco-compensation can promote harmony between regional eco-resource utilization and a region's bearing capacity. The promotion of harmonious regional development relies on the rational development and utilization of natural ecological resources, and this requires the coordination of natural and ecological re- source development, carrying capacity, and utilization load pressure. The ecological development and construction activities of humankind must occur within the boundaries set by the ecological carrying capacities of the resources concerned. By implementing eco-compensation and realizing the balance between ecological resources and carrying capacity, ecological resources can be used sustainably.

Secondly, eco-compensation can promote harmony between regional developmental needs and the exploitation and utilization of ecological resources. China is one of the world's largest countries in terms of types and quantities of ecological resources, but its per capita ecological resources are relatively small, and the regional distribution of ecological resources is very uneven. To continuously meet the needs of human social development, every region must constantly develop and utilize new ecological resources. However, there are great resource endowment differences among various areas in China. Eco-compensation is an important means by which to maximize the value of eco-resource utilization and to optimize the allocation of different resources, in order to promote harmonious regional development.

Third, eco-compensation can promote harmony between related, eco-resource development benefit groups. Due to the imbalance of temporal and spatial ecoresource distribution, and the mobility of some ecological resources and pollutants that arise during the development process, regional effects vary widely during the development of ecological resources. For example, because of the mobility of water ecological resources,

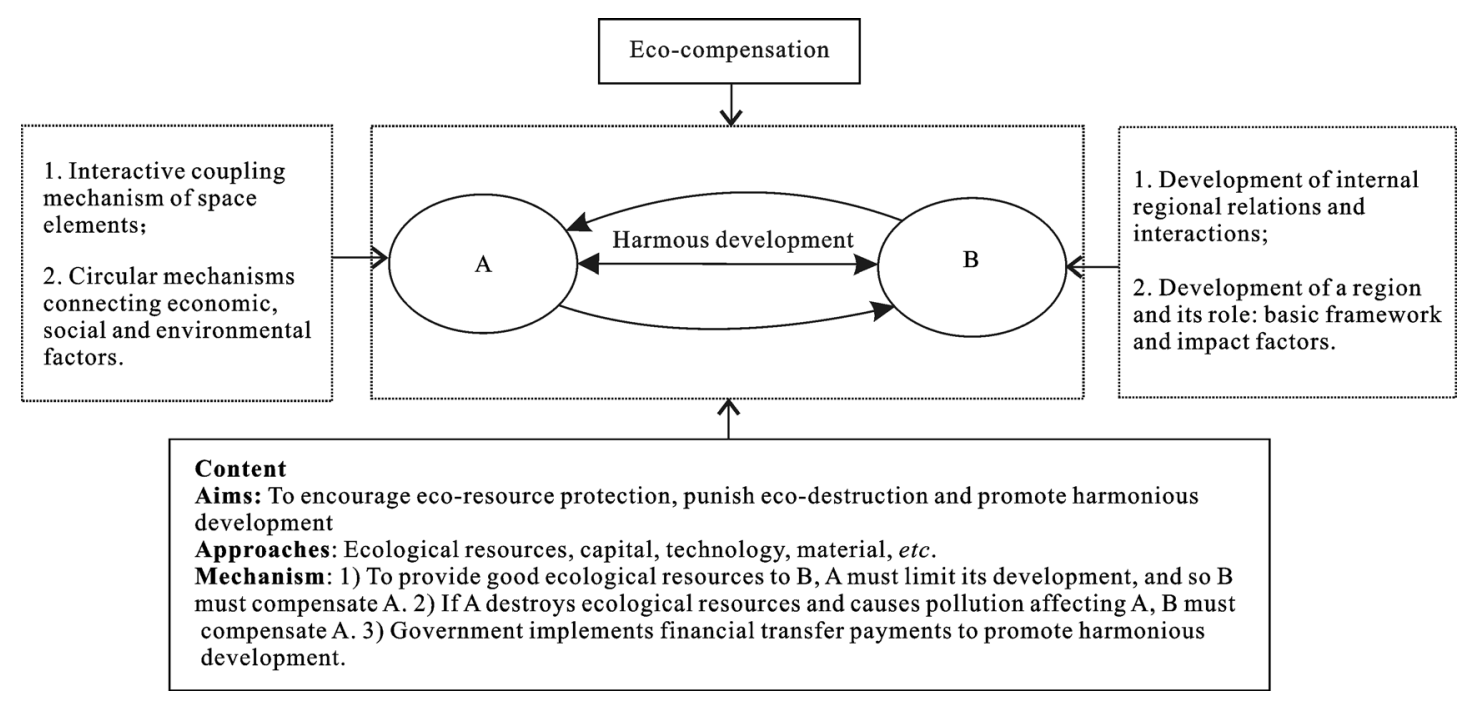

Fig. 1 Basic elements of eco-compensation 
there will be eco-resource benefit differences between upstream and downstream areas. These differences need to be regulated and controlled by eco-compensation. In this way harmonious regional development can be achieved.

\section{Eco-compensation Situations in China}

\subsection{Overall situations}

The overall eco-compensation situation in China can be summarized by five points. First, many eco-compensation projects were implemented by the government. Spontaneous compensation is much more limited. Central, provincial (municipality, autonomous region) and local governments were the dominant powers in eco-compensation. National eco-compensation financial transfer payments, enterprises' eco-compensation penalties, and related ecological resources taxes were all controlled and coordinated by government bodies. For example, the Chinese central government established a central government forest ecological benefits compensation fund system, a grassland eco-compensation mechanism, a water resource and soil conservation eco-compensation mechanism, a key ecological function zone transfer payment system, etc., and formed 'draft ecocompensation rules'. Many provincial (municipality, autonomous region) and local governments also introduced policies. Examples include 'Shanghai establishing and perfecting eco-compensation mechanism opinions', 'Zhejiang Province People Government perfecting eco-compensation mechanism opinions', 'Guangdong Province eco-compensation method', 'Henan Province water environment eco-compensation interim procedures', 'Shanxi Province ecological environment compensation rules', 'Three river source region eco-compensation trial rules', 'Hainan Province central mountainous area eco-compensation trial rules', etc. But there were few reports of person to person, collective to collective, business to person, or other spontaneous forms of eco-compensation.

Second, eco-compensations were mainly paid by the central government, with few cases of compensation from local sources, although some contributions from the central government are combined with contributions from province (municipality, autonomous region) governments. Local governments are still the main recipients of eco-compensation, and they share the funds with farmers and herdsmen. According to statistics, from 2001 to 2012, the Chinese central government's key ecological function zone transfer payment amounted to $1.101 \times 10^{11}$ yuan $(\mathrm{RMB})$, the central government's forest ecological benefits compensation fund expended $5.49 \times 10^{10}$ yuan (RMB), the central government's grassland eco-compensation fund amounted to $2.86 \times 10^{10}$ yuan (RMB), the central government's water and soil conservation fund came to $2.69 \times 10^{10}$ yuan (RMB), and the central government's mine geological environment special fund reached $2.37 \times 10^{10}$ yuan $(\mathrm{RMB})(\mathrm{Xu}$, 2013).

Third, many eco-compensation payments are made within provinces, with fewer inter-provincial compensation payments. Inter-provincial eco-compensation is limited by administrative competition, and the lack of related, national-level operational policies. Inter-provincial eco-compensation is still in an experimental stage. At present, there are just a few trans-provincial ecocompensation cases, such as Weihe River management eco-compensation scheme between Shaanxi Province and Gansu Province, and the Xin'an River Basin ecocompensation between Zhejiang Province and Anhui Province.

Fourth, many eco-compensation payments were transfer payments, with relatively few compensation payments and penalties. In China's current vertical management system, the central government is still the principal player in the field of eco-compensation. According to statistics, from 2001 to 2012, the total eco-compensation capital investment from Chinese central finance stood at $2.50 \times 10^{11}$ yuan $(\mathrm{RMB})$, increasing from $2.3 \times 10^{9}$ yuan $(\mathrm{RMB})$ in 2001 to $7.8 \times 10^{10}$ yuan (RMB) in 2012 (Xu, 2013). It remains difficult to implement eco-compensation between different direct interest-related subjects except via a market mechanism.

Fifth, many eco-compensation projects are implemented in rich areas, with fewer occurring in poor provinces. Relatively speaking, eco-compensation payments were greater in Beijing, Shanghai, Guangdong, Tianjin, and other wealthy provinces than in Anhui, Tibet, and poorer provinces. Taking the national public welfare forest eco-compensation payment standard as an example, in Xinjiang, Qinghai, and other poor provinces it averaged 75 yuan (RMB) per year per Ha, whereas in Beijing, Shanghai, and other wealthy provinces it reached 150-269 yuan (RMB). 


\subsection{Ways of eco-compensation in each province}

After an inductive statistical study of the typical ways of eco-compensation at home and abroad, about 40 ways of eco-compensation were identified. In China, from the provincial angle, only Beijing implemented comprehensive compensation by constructing an ecological conservation area. Forest eco-compensation is the most common way of eco-compensation. Nearly every province (municipality, autonomous region) has implemented it. To Shanxi, Hebei, Liaoning, Jiangsu, Anhui, Shandong, Henan, Hunan, Hubei, Jiangxi, Guangxi, Guizhou, Yunnan, Shaanxi and other relatively developed river-basin provinces (municipality, autonomous region), river basin eco-compensation accounted for a major proportion. Shanxi, Hunan, Yunnan, Shaanxi, Qinghai, Xinjiang and other provinces (municipality, autonomous region) have implemented mineral ecocompensation. Wet land eco-compensation was implemented in Tianjin, Heilongjiang, Jiangsu, Jiangxi, Guangdong, Qinghai and other provinces (municipality, autonomous region). Ocean eco-compensation was implemented in Liaoning, Shandong and other coastal provinces. Tianjin municipality was the first to implement garbage disposal eco-compensation. Grassland eco-compensation was implemented in Xinjiang, Ningxia, Qinghai, Gansu, Tibet, Heilongjiang, Jilin, Inner Mongolia and other provinces (municipality, autonomous region). Jiangsu Province and Hunan Province implemented landscape and famous scenery (nature protection area) eco-compensation. The ways of eco-compensation in each province are summarized in Table 2.

Table 2 Ways of eco-compensation in each province in China

\begin{tabular}{|c|c|}
\hline Province & Eco-compensation way \\
\hline Beijing & Construction of eco-conservation development areas, mountain eco-compensation \\
\hline Tianjin & Forest, wetland, and garbage disposal eco-compensation \\
\hline Inner Mongolia & Steppe and forest eco-compensation and eco-migrants \\
\hline Shanxi & Coal mining, pollution, forest, and interprovincial watershed eco-compensation \\
\hline Hebei & Watershed and forest eco-compensation \\
\hline Liaoning & Watershed (including interprovincial watershed eco-compensation), forest, and ocean eco-compensation \\
\hline Jilin & Forest and grassland eco-compensation \\
\hline Heilongjiang & Forest, wetland, and grassland eco-compensation \\
\hline Shanghai & Water source area and public welfare forest eco-compensation \\
\hline Jiangsu & Watershed, forest, south-to-north water diversion, ocean, wetland, and famous scenic area eco-compensation \\
\hline Zhejiang & Regional and forest eco-compensation \\
\hline Anhui & Watershed (including interprovincial watershed eco-compensation) and forest eco-compensation \\
\hline Fujian & Watershed (upstream and downstream) and forest eco-compensation \\
\hline Shandong & Ocean, watershed, and forest eco-compensation \\
\hline Henan & Watershed, forest, water environment, and south-to-north water diversion eco-compensation \\
\hline Hunan & Diversification \\
\hline Hubei & Forest, water and soil conservation, and south-to-north water diversion eco-compensation \\
\hline Jiangxi & Wetland, forest, and watershed eco-compensation \\
\hline Guangdong & Eco-functional region, forest, and wetland eco-compensation \\
\hline Guangxi & Forest and interprovincial watershed eco-compensation \\
\hline Hainan & Reservoir, city water source, and mountain eco-compensation \\
\hline Chongqing & Forest and local public welfare forest eco-compensation \\
\hline Sichuan & Forest and local public welfare forest eco-compensation and eco-conservation demonstration zone' construction \\
\hline Guizhou & Water pollution' prevention and control, public welfare forest, forest, and watershed eco-compensation \\
\hline Yunnan & Mineral resources exploitation, river and watershed, and forest eco-compensation \\
\hline Tibet & Steppe and forest eco-compensation \\
\hline Shaanxi & Provincial level watershed, water and soil conservation, and coal exploitation eco-compensation \\
\hline Gansu & Forest, steppe, public welfare forest, and fishing engineering eco-compensation \\
\hline Qinghai & Three rivers' source area, primary minerals, public welfare forest, steppe, and plateau wetland eco-compensation \\
\hline Ningxia & Forest and steppe eco-compensation \\
\hline Xinjiang & Forest, steppe, and resource exploitation (coal, oil) eco-compensation \\
\hline
\end{tabular}




\section{Typical Models of 'Eco-compensation'}

Based on the practice of eco-compensation and regional development in China, drawing on existing research results (Sun et al., 2006; Hu, 2007; Yu and Ren, 2008; Sun et al., 2009; Xu, 2011; Zeng, 2012), and in the light of the type, method and name attached to eco-compensation programs, four typical models of eco-compensation and harmonious regional development can be identified in China (Fig. 2, Table 3).

\subsection{Government financial transfer payment com- pensation model}

To protect forest, grassland, and other basic strategic ecological resources of the country and promote the construction of an ecologically and environmentally friendly society, the central government plays a lead role, and the province governments (municipality, autonomous region) draft relevant policy documents, designate ecological resources (national level, provincial level, etc.), and pay certain amounts of eco-compensation money for resource protection areas every year in the form of financial transfer payments. The eco-compensation money is mainly used to pay the wages of the ecological resources manager, local government management fees, and other essential infrastructure construction and administrative costs. The essential characteristic of this model is that the government maintains and improves ecological services by means of financial transfer payments, direct investments, subsidies, preferential tax policies, etc. The eco-compensation recipients are the eco-service providers (individual or company) who protect and manage ecological resources. This is the most common eco-compensation model in China at present. Implementing this model needs vigorous government financial and administrative support. The main method is the key ecological function zone transfer payment.

\subsection{Ecological resource exploiters' payment com- pensation model}

Resource scarcity, national political authority, and social, moral, and civic awareness results in public recognition of the value of ecological resources and the establishment of an ideological understanding and a social value concerning the payment for the use of ecological resources. The resources collected by the government from resource exploiters and users provide the necessary funding for eco-compensation after resource exploitation. The essential characteristic of this model is that the administrative power of the state enables it to require ecological resources exploiters (enterprises) first to pay the resource exploitation security deposit and eco-resource recovery fee prior to getting permission to exploit ecological resources. Implementing this model needs sound environmental policy and government power, and, at the same time, needs ecological environmental awareness on the part of ecological resources exploiters. Typical examples are the resource funds collected for the development and utilization of mineral and ocean resources.

Table 3 Characteristics and applicability of typical eco-compensation models

\begin{tabular}{|c|c|c|}
\hline Model name & Characteristic & Applicability \\
\hline $\begin{array}{l}\text { Government } \\
\text { finance transfer } \\
\text { payment compensation } \\
\text { model }\end{array}$ & $\begin{array}{l}\text { The eco-compensation provider is the government. The eco-compensation recipient is } \\
\text { the eco-service provider (individual or company) who produces and manages eco- } \\
\text { logical resources. The methods of eco-compensation government financial trans- } \\
\text { fer payments, direct investment, subsidies, preferential tax policies, etc. }\end{array}$ & $\begin{array}{l}\text { The most common eco-compensation model } \\
\text { in China at present. }\end{array}$ \\
\hline $\begin{array}{l}\text { Ecological } \\
\text { resource users' } \\
\text { payment compensation } \\
\text { model }\end{array}$ & $\begin{array}{l}\text { The eco-compensation provider is the ecological resources exploiter (enterprise). The } \\
\text { eco-compensation recipient is eco-resource protector and repairer, local residents and the } \\
\text { government. The method of eco-compensation is the payment of the resource exploita- } \\
\text { tion security deposit and eco-resource recovery fee which the company is charged. }\end{array}$ & $\begin{array}{l}\text { Mineral and other ecological resources ex- } \\
\text { ploited in a resource-centred region. }\end{array}$ \\
\hline $\begin{array}{l}\text { Eco-environment } \\
\text { destroyer } \\
\text { compensation model }\end{array}$ & $\begin{array}{l}\text { The eco-compensation provider is the ecological environment destroyer. The } \\
\text { eco-compensation recipient is those who suffer benefit loss due to the destruction of } \\
\text { the ecological environment. The method of eco-compensation way is negotiation. }\end{array}$ & $\begin{array}{l}\text { Trans-regional environmental pollution, the } \\
\text { subject that causes ecological damage and the } \\
\text { subject that suffers damage (upstream and } \\
\text { downstream in the same drainage basin). }\end{array}$ \\
\hline $\begin{array}{l}\text { Ecological resource tax } \\
\text { collection compensation } \\
\text { model }\end{array}$ & $\begin{array}{l}\text { The eco-compensation provider is the user of ecological resources. The } \\
\text { eco-compensation recipient is the commonly-owned ecological resources developer } \\
\text { and administrator (represented by the government). The method of eco-compensation } \\
\text { way is the collection of the eco-resource tax. }\end{array}$ & $\begin{array}{l}\text { Collection of water tax, gas tax, petroleum } \\
\text { tax, etc. }\end{array}$ \\
\hline
\end{tabular}




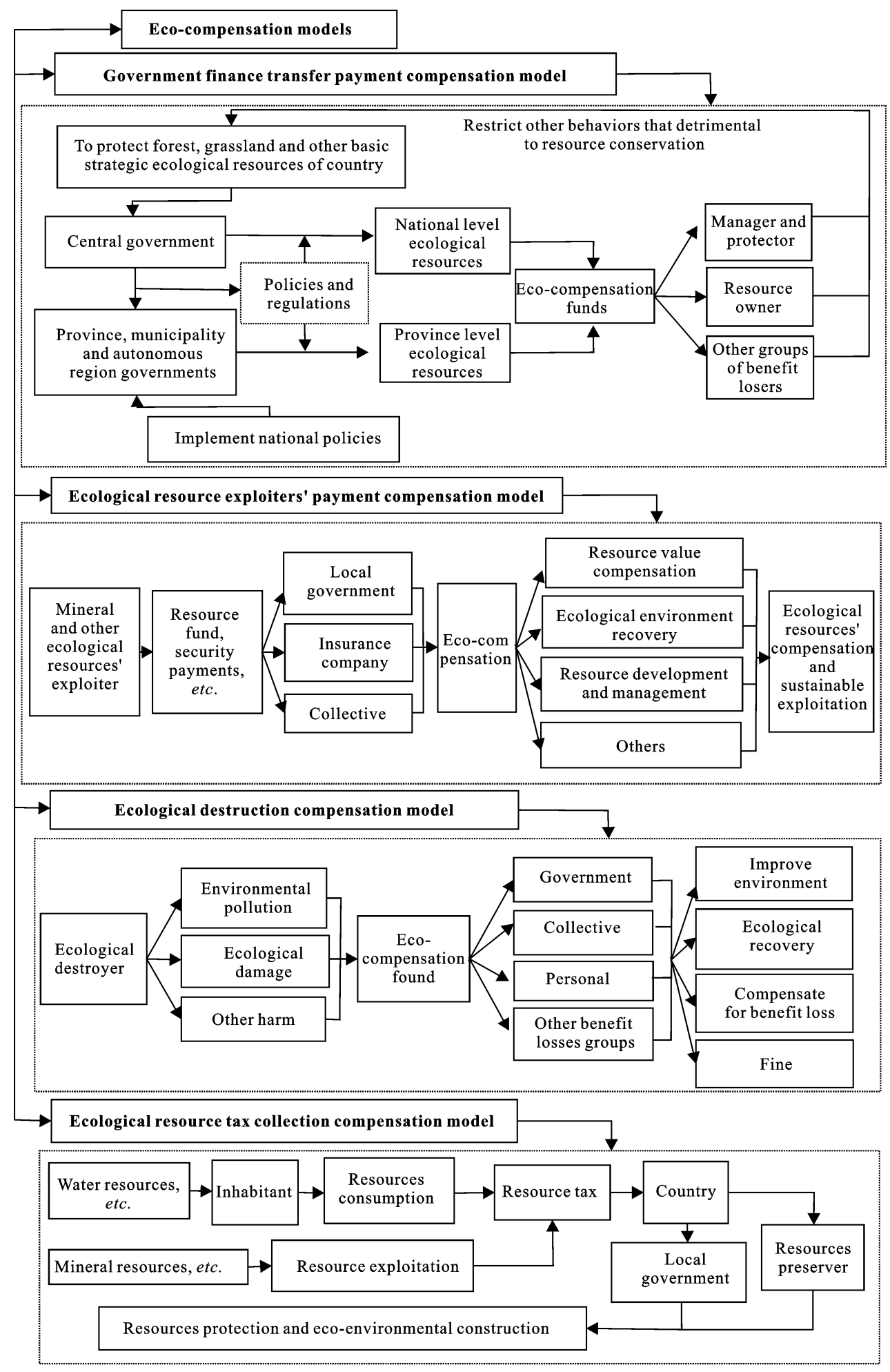

Fig. 2 Basic framework of four typical eco-compensation models

\subsection{Ecological destruction compensation model}

Because of the mobility of some ecological resources (water, air, etc.), behavior that causes eco-environmental destruction not only causes environmental pollution, results in ecological damage and has other negative effects on ecological resources, but also gives rise to conflicts of interest between different groups with respect to production, life and ecology. To solve environmental 
problems, the eco-environment destroyer should compensate other groups for benefit losses, and should pay certain eco-environment compensation founds to those who suffer from environmental damage. Implementing this model requires negotiation between ecological environment destroyers and benefit losers, and also requires negotiation between ecological service providers and potential users, who then make a deal or reach a compensation agreement. Typical examples are environmental pollution problems involving upstream and downstream areas, interprovincial watershed eco-compensation, etc.

\subsection{Ecological resource tax collection compensa- tion model}

For water, energy, and other strategic natural resources, governments collect coal, oil, natural gas, minerals and other resource taxes. These taxes reflect the chargeable use of state-owned natural resources with the aim of adjusting differences in profitability derived by taxpayers with differential access to natural resources and of promoting effective resource development and sustainable use. As a result society can provide the necessary eco-compensation for resource exploitation. Operating in the context of the functioning of market mechanisms and on the basis of market rules, the government represents the ecological service supplier, and collects taxes from the suppliers which are reflected in the prices charged to users of the services the resources provide, and carries out ecological compensation work for the eco-resource beneficiaries. In the implementation of this type of eco-compensation model, market mechanisms guaranteed by government power are the basis. Typical examples are water tax, natural gas tax, petroleum tax, etc.

\section{Conclusions and Future Prospects}

(1) Eco-compensation is a response to growing pressures from eco-resource damage and pollution and can help promote harmonious regional development. How nature and natural resources should be valued and therefore how much compensation is appropriate, who should compensate whom (who pays what and who receives what), and how compensation payments should be made are the core problems that still remain to be addressed.

(2) Eco-compensation in China has had significant impacts. In each province in China, there are different key areas of work in relation to eco-compensation. Many eco-compensation projects are led by the government; spontaneous compensation is much less frequent. Similarly, eco-compensation is mainly paid for by government, with fewer funds coming from local sources. Most eco-compensation transactions occur within rather than between provinces. Transfer payments are more common than compensation payments and penalties. Finally, eco-compensation is more common in richer areas than in poorer ones.

(3) China has explored several eco-compensation development models. Government financial transfer compensation payments, ecological resources exploiters' payment compensation, ecological destruction compensation, and ecological resources tax collection compensation are the four primary development models. Each model has its own features and norms.

(4) In practice, eco-compensation has made a positive contribution to harmonious regional development in China. However, there is a lack of an overall framework for the development of eco-compensation, and there is no consensus regarding the scientific propositions underpinning eco-compensation models. In particular, studies of the relationship between harmonious regional development and eco-compensation models are still lacking, making it difficult to understand the differences, similarities, complementarities and conflicts between them. This paper has provides an initial theoretical and empirical clarification of some of the issues involved, opening the way to further investigation and analysis.

\section{References}

Babcock B A, Lakshminarayan P G, Wu J D et al., 1997. Targeting tools for the purchase of environmental amenities. Land Economics, 73: 325-39.

Bennett M T, 2008. China's sloping land conversion program: institutional innovation or business as usual? Ecological Economics, 65(4): 699-711. doi: 10.1016/j.ecolecon.2007.09.017

Bienabe E, Hearne R R, 2006. Public preferences for biodiversity conservation and scenic beauty within a framework of environmental services payments. Forest Policy and Economics, 9(4): 335-348. doi: 10.1016/j.forpol.2005.10.002

Brown M A, Clarkson B D, Barton B J et al., 2013. Ecological compensation: an evaluation of regulatory compliance in New Zealand. Impact Assessment and Project Appraisal, 31(1): 34-44. doi: 10.1080/14615517.2012.762168 
China Ecological Compensation Mechanism and Policy Research Team, 2007. China Ecological Compensation Mechanism and Policy Research. Beijing: Science Press. (in Chinese)

Coase R H, 1960. The problem of social cost. The Journal of Law and Economic, 8(3): 1-44

Cowell R, 2000. Environmental compensation and the mediation of environmental change: making capital out of Cardiff Bay. Journal of Environmental Planning and Management, 43(5): 689-710. doi: 10.1080/713676580

Cowell R, 1997. Stretching the limits: environmental compensation, habitat creation and sustainable development. Transactions of the Institute of British Geographers, 22(3): 292-306. doi: 10.1111/j.0020-2754.1997.00292.x

Cuperus R, Canters K J, Piepers A A G, 1996. Ecological compensation of the impacts of a road. Preliminary method for the A50 road link (Eindhoven-Oss, The Netherlands). Ecological Engineering, 7(4): 327-349. doi: 10.1016/S0925-8574(96) 00024-9

Cuperus R, Canters K J, Udo de Haes H A et al., 1999. Guidelines for ecological compensation associated with highways. Biological Conservation, 90(1): 41-51. doi: 10.1016/S00063207(99)00007-5

Cuperus R, Bakermans M G G J, UdodeHaes H A et al., 2001. Ecological compensation in dutch highway planning. Environmental Management, 27(1): 75-89. doi: 10.1007/s0026 70010135

Dai Qiwen, Zhao Xueyan, 2010. Discussion on several key scientific issues of eco-compensation mechanism in Gannan Tibetan autonomous prefecture. Acta Geographica Sinica, 65(4): 494506. (in Chinese)

Dai Junhu, Wang Huanjiong, Wang Hongli et al., 2012. An introduction to framework of assessment of the value of ecosystem services. Progress in Geography, 31(7): 963-969. (in Chinese)

Engel S, Pagiola S, Wunder S, 2008. Designing payments for environmental services in theory and practice: an overview of the issues. Ecological Economics, 65(4): 663-674. doi: 10.1016/j.ecolecon.2008.03.011

Fan Jie, 2007. A research on the importance and significance of major function oriented zoning based upon the analysis on the restrictive factors of regional coordinative development. Bulletin of Chinese Academy of Sciences, 22(3): 194-201. (in Chinese)

Hou Chengcheng, Zhao Xueyan, Zhang Li et al., 2012. The impacts of ecological compensation on regional development: a case of the Yellow River water supply areas of Gannan. Journal of Natural Resources, 27(1): 50-61. (in Chinese)

Hou Chengcheng, Zhao Xueyan, Zhang Li et al., 2011. Advances on the impacts of ecological compensation to regional development. Chinese Agricultural Science Bulletin, 27(11): 104107. (in Chinese)

$\mathrm{Hu}$ Yiyuan, 2007. Eco-compensation models of regional economic development. Social Science Journal, (4): 123-127. (in Chinese)

Jenkins M, Scherr S, Inbar M, 2004. Markets for biodiversity services: potential roles and challenges. Environment: Science and Policy for Sustainable Development, 46(6): 32-42. doi: 10.1080/ 00139157.2004.10545160

Johnson J, Maxwell B, 2001. The role of the conservation reserve program in controlling rural residential development. Journal of Rural Studies, 17(3): 323-332. doi: 10.1016/S0743-0167(00) 00053-X

Kalacska M, Sanchez-Azofeifa G A, Rivard B et al., 2008. Baseline assessment for environmental services payments from satellite imagery: a case study from Costa Rica and Mexico. Journal of Environmental Management, 88(2): 348-359. doi: 10.1016/j.jenvman.2007.03.015

Kosoy N, Martinez-Tuna M, Muradian R et al., 2007. Payments for environmental services in watersheds: insights from a comparative study of two cases in Central America. Ecological Economics, 61(2): 446-455. doi: 10.1016/j.ecolecon.2006.03. 016

Li Huaien, Shi Shujuan, Dang Zhiliang et al., 2009. Study on eco-compensation mechanism in Shaanxi water source of middle line South-to-North water transfer project. Journal of Natural Resources, 24(10): 1764-1771. (in Chinese)

Li Wenhua, Li Shidong, Li Fen et al., 2007. Discussions on several issues of forest eco-compensation mechanism. China Population Resources and Environment, 17(2): 13-18. (in Chinese)

Li Wenhua, Li Fen, Li Shidong et al., 2006. The status and prospect of forest ecological benefit compensation. Journal of Natural Resources, 21(5): 677-688. (in Chinese)

Liu Yu, 2007. Regional harmonious development and ecological compensation for trans-regional resources allocation. Macroeconomic Management, (11): 24-27. (in Chinese)

Locatelli B, Rojas V, Salinas Z, 2008. Impacts of payments for environmental services on local development in northern Costa Rica: a fuzzy multi-criteria analysis. Forest Policy and Economics, 10(5): 275-285. doi: 10.1016/j.forpol.2007.11.007

Lu Dadao Fan Jie, 2012. The rise and effects of regional sustainable development studies in China. Bulletin of Chinese Academy of Sciences, 27(3): 290-300, 319. (in Chinese)

Lu Dadao, Liu Weidong, 2000. Analysis of geo-factors behind regional development and regional policy in China. Scientia Geographica Sinica, 20(6): 487-493. (in Chinese)

Ma Aihui, Cai Yinying, Zhang Anlu, 2012. An empirical study of cultivated land ecological compensation based on choice experiments method. Journal of Natural Resources, 27(7): 1154-1163. (in Chinese)

Mäler K G, 2000. Development, ecological resources and their management: a study of complex dynamic systems. European Economic Review, 44(4): 645-665. doi: 10.1016/S0014-2921 (00)00043-X

Mao Xianqiang, Zhong Yu, Zhang Sheng, 2002. Conception, theory and mechanism of eco-compensation. China Population, Resources and Environment, 12(4): 38-41. (in Chinese)

Mao Zhanyeng, Wang Yaping, 2008. Standard accounting in ecology compensation of water diversion between valleys. Journal of Hunan Institute of Engineering (Social Science Edi- 
tion), 18(2): 15-18. (in Chinese)

Mao Feng, Zeng Xiang, 2006. The mechanisms and principles of ecological compensation. Acta Ecologica Sinica, 26(11): 38413846. (in Chinese)

Merlo M, Rojas Briales E, 2000. Public goods and externalities linked to Mediterranean forests: economic nature and policy. Land Use Policy, 17(3): 197-208. doi: 10.1016/S0264-8377 (00)00017-X

Millennium Ecosystem Assessment, 2005. Ecosystems and Human Well-being: Synthesis. Island Press, Washington, DC.

Muñoz-Piña C, Guevara A, Torres J M et al., 2008. Paying for the hydrological services of Mexico's forests: analysis, negotiations and results. Ecological Economics, 65(4): 725-736. doi: 10.1016/j.ecolecon.2007.07.031

Muradian R, Rival L, 2013. Governing the Provision of Ecosystem Services, Studies in Ecological Economics. Springer Science, 235-255. doi: 10.1007/978-94-007-5176-7_12.

Murray B C, Abt R C, 2001. Estimating price compensation requirements for eco-certified forestry. Ecological Economics, 36(1): 149-163. doi: 10.1016/S0921-8009(00)00224-X

Pagiola S, 2008. Payments for environmental services in Costa Rica. Ecological Economics, 65(4): 712-724. doi: 10.1016/j. ecolecon.2007.07.033

Pagiola S, Arcenas A, Platais G, 2005. Can payments for environmental services help reduce poverty? An exploration of the issues and the evidence to date from Latin America. World Development, 33(2): 237-253. doi: 10.1016/j.worlddev.2004.07.011

Pagiola S, Platais G, 2007. Payments for Environmental Services: From Theory to Practice. Washington D C: World Bank.

Pan Lihu, Huang Heqing, Jiang Luguang et al., 2010. A case study of the effects of wetland restoration policy with an artificial society model. Journal of Natural Resources, 25(12): 2007-2017. (in Chinese)

Pascual U, Muradian R, Rodríguez L C et al., 2010. Exploring the links between equity and efficiency in payments for environmental services: a conceptual approach. Ecological Economics, 69(6): 1237-1244. doi: 10.1016/j.ecolecon.2009.11.004

Qin Yanhong, Kang Muyi, 2007. A review of ecological compensation and its improvement measures. Journal of Natural Resources, 22(4): 557-567. (in Chinese)

Rundcrantz K, Skärbäck E, 2003. Environmental compensation in planning: a review of five different countries with major emphasis on the German system. European Environment, 13(4): 204-226. doi: 10.1002/eet.324

Sara J, Scherr A W, 2002. Outline for presentation-factors to consider in choosing instruments to promote environmental services. Workshop on Payment Schemes for Environmental Services, Apr. 22-23, Beijing.

Scott M J, Bilyard G R, Link S O et al., 1998. Valuation of ecological resources and functions. Environmental Management, 22(1): 49-68. doi: 10.1007/s002679900083

Sommerville M, Jones J P G, Rahajaharison M et al., 2010. The role of fairness and benefit distribution in community-based payment for environmental services interventions: a case study from Menabe, Madagascar. Ecological Economics, 69(6):
1262-1271. doi: 10.1016/j.ecolecon.2009.11.005

Straton A, 2006. A complex systems approach to the value of ecological resources. Ecological Economics, 56(3): 402-411. doi: 10.1016/j.ecolecon.2005.09.017

Sun Xinzhang, Zhou Hailin, 2008. Key problems of eco-compensation system building in China and strategies for resolving them. China Population Resources and Environment, 18(5): 139-143. (in Chinese)

Sun Haiyan, 2007. A study on the mechanism construct of regional coordination development. Economic Geography, 27(3): 362-365. (in Chinese)

Sun Xinzhang, Zhou Hailin, Zhang Xinmin, 2009. The necessary conditions and grading development theory for improving the eco-compensation system in China. Resources Science, 31(8): 1349-1354. (in Chinese)

Sun Xinzhang, Xie Gaodi, Zhang Qizi et al., 2006. Ecological compensation practice and policy orientation in China. Resources Science, 28(4): 25-30. (in Chinese)

Tschakert P, 2007. Environmental services and poverty reduction: options for smallholders in the Sahel. Agricultural Systems, 94(1): 75-86. doi: 10.1016/j.agsy.2005.07.010

Wang Jinlong, Ma Weiming, 2002. Study of valley ecology compensation question. Journal of Soil Water Conservation, 16(6): 82-83. (in Chinese)

Wang Yu, 2009. The Exploring in Fundamental Theories and Practical Issues of Regional Ecological Compensation. Changchun: Northeast Normal University. (in Chinese)

Wu Xiaoqing, Hong Shangqun, Duan Changqun et al., 2003. Inter-regional ecological compensation system and regional coordinative development. Resources and Environment in the Yangtze Basin, 12(1): 13-16. (in Chinese)

Wunder S, 2005. Payments for environmental services: some nuts and bolts. Jakarta, Indonesia: CIFOR, 3-8.

Wunder S, Albán M, 2008. Decentralized payments for environmental services: the cases of Pimampiro and PROFAFOR in Ecuador. Ecological Economics, 65(4): 685-698. doi: 10. 1016/j.ecolecon.2007.11.004

$\mathrm{Xu}$ Shaoshi, 2013. The State Council Report on the Construction Work of Ecological Compensation Mechanism Construction in China. Available at: www.npc.gov.cn.

Xu Mengyue, Chen Jianglong, Gao Jinlong et al., 2012. Study on ecological compensation model for major function oriented zones. Chinese Journal of Eco-Agriculture, 20(10): 14041408. (in Chinese)

$\mathrm{Xu}$ Yongtian, 2011. Research on ecological compensation mode and practice in China. Yangtze River, 42(11): 68-73. (in Chinese)

Yang B, Busch J, Zhang L et al., 2013. Eco-compensation for giant panda habitat. Science (New York, NY), 339(6119): 521-521.

Yang Baojun, 2004. On the coordination of regional development. City Planning Review, 28(5): 20-24, 42. (in Chinese)

Yang Guangmei, Min Qingwen, Li Wenhua et al., 2007. Scientific issues of ecological compensation research in China. Acta Ecologica Sinica, 27(10): 4289-4300. (in Chinese)

Yu Hai, Ren Yong, 2008. Eco-compensation scheme in China: 
concept, issue types and policy options. China Soft Science, (6): 7-15. (in Chinese)

Zeng Yu, 2012. Study of Watershed Ecological Compensation Mode in China. Nanjing: Nanjing University. (in Chinese)

Zhang Wei, Zhang Hongye, Zhang Yifeng, 2010. The determination of social ecological compensation standard based on 'Equivalent Value of Geographical Factor Endowment'. Acta Geographica Sinica, 65(10): 1253-1265. (in Chinese)

Zhang Jinquan, 2007. Ecological supplementary mechanism and the coordinated regional development. Journal of Lanzhou University (Social Sciences), 35(3): 115-119. (in Chinese)

Zheng Haixia, Zhang Lu, 2006. Research on the standardization of compensation for the service of eco-system in river valley. Environmental Protection A, (1): 42-45. (in Chinese)

Zhi Ling, Li Nuyun, Tian Zhiwei et al., 2004. Evaluation of social impacts of the project of conversing cropland to forestland in the western China: taking Huize County and Qingzhen as example. Scientia Silvae Sinicae, 40(3): 2-11. (in Chinese) 